\title{
"EL PERÚ Y BOLIVIA ANTE EL GENERAL PILILO": LOS ENEMIGOS DE CHILE EN LAS CARICATURAS DE LA GUERRA DEL PACÍFICO (1879-1883)
}

\author{
“PERU AND BOLIVIA IN THE PRESENCE OF GENERAL PILILO”: CHILEAN \\ ENEMIES IN WAR OF THE PACIFIC'S CARTOONS (1879-1883)
}

\author{
Patricio Ibarra Cifuentes*
}

\begin{abstract}
Durante la guerra del Pacífico (1879-1883) los caricaturistas chilenos, mediante grabados dados a la luz en las páginas de los principales periódicos de humor gráfico del país, difundieron en la opinión pública chilena una representación despectiva de las repúblicas de Perú y Bolivia beligerantes con Chile en dicho conflicto. Se trató de discurso visual agresivo, que hizo uso de la sátira mordaz, desde el punto de vista nacionalista, y destinado a inducir en sus lectores una imagen crítica y despreciativa de los adversarios de Chile. Vituperaron tanto a gobernantes como a la población de las naciones "enemigas" mediante un lenguaje racista desproporcionado, mostrándolos como inferiores a los chilenos. Con esos grabados se imputó a peruanos y bolivianos atributos negativos, en concordancia con el clima bélico imperante. Así, los pinceles, la tinta y el papel se transformaron en otra de las muchas armas implicadas en la guerra de 1879.
\end{abstract}

Palabras claves: Guerra del Pacífico, prensa satírica, caricaturas chilenas.

During the War of the Pacific (1879-1883) Chilean cartoonists, through engravings given to light in the pages of the major newspapers of humor of the country, broadcast on Chilean public opinion a derogatory representation of the Republics of Peru and Bolivia belligerents with Chile in the conflict. It was aggressive visual speech, which made use of biting satire, nationalistic key, and intended to induce their readers a critical and contemptuous of the adversaries of Chile image. They excoriated both rulers and the people of the "enemy" nations, through a disproportionate racist language, showing them as inferior to Chileans. Through these engravings, Peruvians and Bolivians negative attributes, in accordance with the prevailing climate of war will be charged. Thus, brushes, ink and paper, they became one of the many weapons involved in the war of 1879.

Key words: War of the Pacific, satiric press, chilean cartoons.

\section{Introducción}

El estallido de la guerra del Pacífico en febrero de 1879 provocó que la atención de la sociedad chilena se volcara al conflicto que nuevamente la enfrentaría contra sus vecinos del norte. Igual que entre 1837 y 1839 , los chilenos habrían de ir a combatir a tierra extraña contra los aliados peruanos y bolivianos, esta vez no por la unión de ambos Estados en una Confederación, sino por la disputa relacionada con la posesión de los ricos territorios salitreros de Antofagasta y Tarapacá. Consecuentemente con ello, la prensa volcó también gran parte de su interés y recursos para informar y comentar los hechos que se producían primero en el frente de batalla. Como es natural, gran parte del espacio dedicado a las noticias de actualidad se consagró a cubrir las alternativas del conflicto que se iniciaba, mediante las crónicas de los corresponsales de guerra y columnas de opinión.
Al confirmarse ante el gran público la existencia del Tratado Secreto de 1873, que unía al Perú y Bolivia en una alianza defensiva, en los periódicos se desplegó una retórica y un discurso agresivo con un marcado tono belicista y nacionalista caracterizado por el intento de vituperar sus instituciones, cultura, población y actuar de ambas naciones en la guerra que se iniciaba (Rubilar 2010). Esa manera de representar a los vecinos del norte también adquirió rasgos racistas, emparentados con la necesidad de dotar de un sentido unitario al conflicto y de diferenciar culturalmente a ambos bandos, en torno a la dicotomía metafórica del "roto" chileno versus el "cholo" peruano y el "cuico" boliviano (Arellano 2012 y Mc Evoy 2012) ${ }^{1}$. Aquello fue uno de los ejes en los que se condujo el debate de la opinión pública chilena respecto del acontecer político, económico, social y cultural durante los años de la guerra del Pacífico ${ }^{2}$.

\footnotetext{
* Universidad Bernardo O’Higgins, Centro de Estudios Históricos, Santiago, Chile. Correo electrónico: patricio.ibarra@ubo
} 
La prensa de sátira profundizó esa lógica. Tanto en sus editoriales, artículos, versos y especialmente en sus caricaturas peruanos y bolivianos fueron presentados como el enemigo que debía ser derrotado. Además, en la medida que la suerte de las acciones bélicas favoreció a las armas chilenas, aquella noción se profundizó, dando paso a una diatriba cada vez más cáustica y despectiva. En ese sentido, la estrategia periodística de los editores de los periódicos de humor y la visión presentada respecto de los aliados fue coherente con la de los diarios de noticias. Empero, merced a las características propias del lenguaje, la sátira, escrita y visual, les permitió ir más allá en la representación crítica de peruanos y bolivianos ${ }^{3}$.

Así, la imagen proyectada en los grabados fue negativa, mostrándose a peruanos y bolivianos como seres temerosos, deformes, abyectos, peligrosos, entre otras representaciones. Según Peter Burke, la creación de estereotipos y su proliferación masiva no solo obedece a la voluntad del autor de una imagen, sino también a los deseos voyeuristas de quienes las observan (Burke 2001). En este caso, las imágenes presentadas por los rotativos de sátira son en parte la materialización de ideas de superioridad en la sociedad chilena respecto de sus vecinos del norte, incubadas durante décadas antes al conflicto de 1879 (Collier 2005). Esas ideas se fortalecieron por la dinámica de lo que Lawrence LeShan denominó "Guerra mítica", caracterizada por la participación de todas las clases sociales en la lucha, la aparición de héroes conocidos por todos, una excitación general por participar de los combates y la idea de formar parte de una cruzada contra el mal, entre otras percepciones. Todo aquello en el contexto de la mentalidad de las sociedades a fines del siglo XIX (LeShan 1992). De ese modo, los dibujos satíricos también se transformaron en un vehículo interpretativo de apreciaciones y expectativas respecto de la guerra en desarrollo, además de modelar ideas y percepciones, e incidir en el conocimiento de personas y hechos vinculados a la guerra. A ello debe sumarse el intento de diferenciación con los adversarios, los que debían ser derrotados por Chile. En síntesis, como lo aseveró Juan Carlos Arellano, peruanos y bolivianos eran "un 'otro' al que había que subyugar o erradicar" (Arellano 2014).

Mediante la fuerza de las imágenes, del humor y la incorrección política, los caricaturistas enseñaron a los observadores de sus obras su visión particular respecto de los enemigos de Chile en la guerra del Pacífico. El mismo acoso burlesco desplegado contra la élite contemporánea, políticos, funcionarios del gobierno, dignatarios de la Iglesia, capitalistas, entre otros, propio de las querellas por el control de la administración del Estado (Salinas 2006), se manifestó con mayor crudeza contra peruanos y bolivianos.

Así, el análisis de la iconografía presente en la prensa de sátira contemporánea al conflicto permite aproximarse desde una perspectiva diferente a la comprensión de cómo la sociedad chilena se informó, involucró, participó y se expresó en los periódicos durante los años de su segundo conflicto contra la alianza formada por Perú y Bolivia.

En las páginas que vienen a continuación se explorará en cómo los rotativos de caricaturas crearon estereotipos satíricos respecto de los enemigos de Chile a sus lectores. Para ello se utilizarán los dibujos satíricos publicados en los periódicos El Barbero, El Corvo, El Ferrocarrilito y El Padre Cobos ${ }^{4}$.

De ese modo se podrá explorar en la imagen construida por la prensa chilena de humor respecto de peruanos y bolivianos, dando cuenta de una de las formas de deliberación y debate producidos en la esfera pública chilena decimonónica mientras en paralelo se desarrollaba un enfrentamiento armado contra dos naciones al unísono, donde fueron utilizados todos los recursos discursivos, retóricos y gráficos disponibles, aprovechando el formato y características de la sátira.

Tan importante como lo anterior, permite establecer cómo en las imágenes presentadas en los periódicos de caricaturas a propósito de los enemigos de Chile sirvieron como vehículo de representación percepciones largamente asentadas en la sociedad chilena, tanto de autovaloración como en la visión de los vecinos, estas se vieron potenciadas por la vorágine del discurso nacionalista y el esfuerzo bélico, todo aquello en el marco de las ideas y valores colectivos correspondientes del último cuarto del siglo XIX en pleno desarrollo de una guerra nacional, periodo clave en la consolidación del Estado Nacional y el sistema republicano, tanto por la expansión territorial como también el afianzamiento de la identidad moderna de los chilenos ${ }^{5}$. En definitiva, una coyuntura que se ha constituido, como lo definió Joaquín Fermandois, en un momento estelar de la historia de Chile (Fermandois 2005). 


\section{La versión satírica de los enemigos de Chile}

Desde su aparición, las caricaturas se constituyeron en un eficaz formato de difusión de puntos de vista y de tentativa por influir en la opinión pública. Cada dibujo implica una aguda reflexión respecto del acontecer de la sociedad, pues enseña al observador de la obra la posición y percepción del autor respecto de los hechos graficados, generalmente relacionados con el quehacer público. En esencia, los rotativos de humor político eran, y continúan siendo, una prensa militante y de batalla, al abanderizarse a favor o en contra de personas, instituciones o ideologías. (Guerrero 1996). En general, desde su irrupción en 1858 con El Correo Literario, los periódicos chilenos de caricaturas adscribieron a los ideales y valores de la modernidad política decimonónica, materializada en el liberalismo republicano, a su vez influenciado por las ideas de las revoluciones francesa de 1830 y 1848, donde se incorporó lenta pero inexorablemente al pueblo, en el lenguaje y simbolismo de la disputa política. Hacia mediados de la década de 1870 , y especialmente la de 1880 , su lenguaje visual y escrito se tornó cada vez más corrosivo y desenfadado, al atacar a personas e instituciones. (Zaldívar 2004 y Salinas 2006).

La prensa de sátira contemporánea a la guerra del Pacífico, igual que la de noticias, poseía una opinión respecto del diario acontecer y se abanderizó ideológicamente, planteando su propio punto de vista y demandas específicas respecto de los temas relacionados con la administración del Estado en general y los relativos al conflicto en particular. No perseguía necesariamente el prurito de la imparcialidad al presentar los hechos (Ossandón 1998). En ese contexto, las materias tratadas por medio de las caricaturas contemporáneas al conflicto de 1879 fueron variadas. Las hubo dedicadas a la conducción política y militar, las victorias chilenas, las consecuencias para los veteranos y la visión de los enemigos de Chile, entre otras. En ocasiones, las imágenes eran apoyadas por un verso en chunga, donde se relataba la situación presentada reforzando así el mensaje que se pretendía transmitir en una imagen. No obstante, la guerra no monopolizó la temática de sus grabados o escritos, pues siempre se refirieron a las luchas partidistas de la época, así fuera la intervención electoral propiciada desde el poder ejecutivo o la lucha por secularización del Estado, y otros temas significativos del período ${ }^{6}$.
Durante los años de guerra los caricaturistas chilenos representaron y crearon estereotipos de peruanos y bolivianos a partir de múltiples imágenes. Como ya se mencionó en líneas precedentes, los periódicos que trataron esa temática fueron $E l$ Barbero, El Corvo, El Ferrocarrilito y El Padre Cobos, estos dos últimos editados por Juan Rafael Allende, ínclito referente de la prensa satírica de fines del siglo XIX en Chile. Estos diarios, en concordancia con el resto de la obra de Allende, mezcló la causa de los chilenos en la guerra del Pacífico con la "agenda liberal" del último cuarto del siglo XIX, vale decir, la lucha por la secularización del Estado, la libertad electoral, la defensa de los derechos del bajo pueblo y de los incipientes grupos medios, entre otras (Salinas 2011, Salinas 2005, Salinas 2006, Cornejo 2006, Ibarra 2013).

Merced a las posibilidades discursivas y estéticas de la caricatura, la forma en cómo fueron presentados a los consumidores de la prensa de sátira planteó la dicotomía metafórica del roto (Chile) versus el cholo (Perú) y el cuico (Bolivia), echando mano a una amplia gama de imágenes con las cuales se representó a los vecinos del norte, cada uno de ellos con sus características propias. Así, en todo cuanto los chilenos eran presentados como ejemplo de los valores permanentes de la humanidad, a sus enemigos se les mostraba cual modelo de decadencia, presentado con el lenguaje burlón y mordaz propio de las caricaturas.

En la medida que el conflicto se desarrolló, aumentando en intensidad y malquerencia entre los beligerantes, la animadversión de la prensa de noticias en general, y la satírica en particular, fue progresivamente concentrándose en Perú, tanto en sus gobernantes como en las personas comunes y corrientes, soldados y civiles. Por su parte Bolivia, considerada como un rival menos importante, fue dejada de lado, en especial luego de que terminara su participación efectiva en el conflicto en mayo de 1880 , tras la derrota de las fuerzas aliadas en la batalla de Tacna y el repliegue del ejército boliviano al Altiplano.

\section{Peruanos y bolivianos en la prensa chilena de caricaturas durante la Guerra del Pacífico}

Tras el éxito de desembarco de las tropas chilenas en Pisagua ( 2 de noviembre de 1879) con que se inició la invasión a territorio peruano, El Barbero de Santiago publicó el 15 de noviembre un grabado 
donde mostró a un martillero recibiendo posturas para adjudicarse dos semovientes "averiados". De izquierda a derecha, el primero de ellos un auquénido, tiene el rostro del presidente de Bolivia general Hilarión Daza. El segundo de los animales, un avestruz andino, caracterizado como el jefe de Estado peruano general Mariano Prado. Ambos animales son propios de cada país (Figura 1).

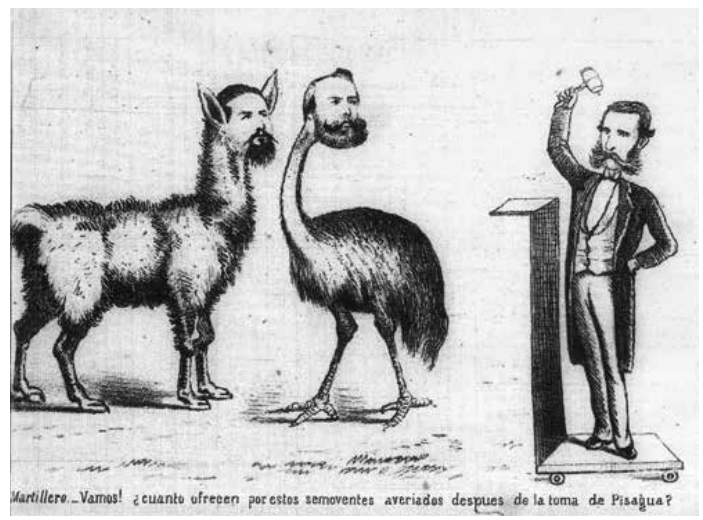

Figura 1. El Barbero (Santiago). Noviembre 15 de 1879.

El mismo 15 de noviembre ante la inminencia del primer canje de prisioneros de la guerra, materializado entre fines de 1879 y comienzos de 1880, El Barbero mostró al segundo comandante de la Esmeralda, teniente $1^{\circ}$ Luis Uribe Orrego, encadenado preguntándose por quiénes será intercambiado él y sus camaradas. Uribe y los chilenos son representados por felinos en actitud feroz, simbolizando su ardor de lucha incombustible, mientras que los aliados Perú-bolivianos lo son por diversas especies de animales inofensivos (conejos, ovejas, etc.) aunque ataviados de indumentaria militar. Existe un único felino del bando aliado, que en la imagen se encuentra de espaldas seguramente en señal de enojo o vergüenza (Figura 2).

Semanas después, tras la culminación de la primera fase de la invasión a la provincia salitrera de Tarapacá, donde los chilenos se hicieron de los ingresos necesarios para continuar la guerra, El Barbero publicó el 29 de noviembre de 1879 una caricatura donde el ministro Domingo Santa María coloca al servicio de la República de Chile a una nueva criada, la del Perú, haciendo hincapié en cuánto dinero ha ocupado en ella, refiriéndose a los innumerables gastos desembolsados a propósito de la guerra. La representación femenina de Chile agrega que su sirvienta le parece, además de costosa, descocada y zafada. Ambas repúblicas son caracterizadas como mujeres, en una versión autóctona y recatada de la Marianne de la Revolución Francesa de 17897 . La del Perú porta en su cabeza un sol, con seguridad alusivo a Inti, denominación quechua del astro rey, máxima deidad inca. Se encuentra vestida con ropas del bajo pueblo, caracterizada como una chola, en

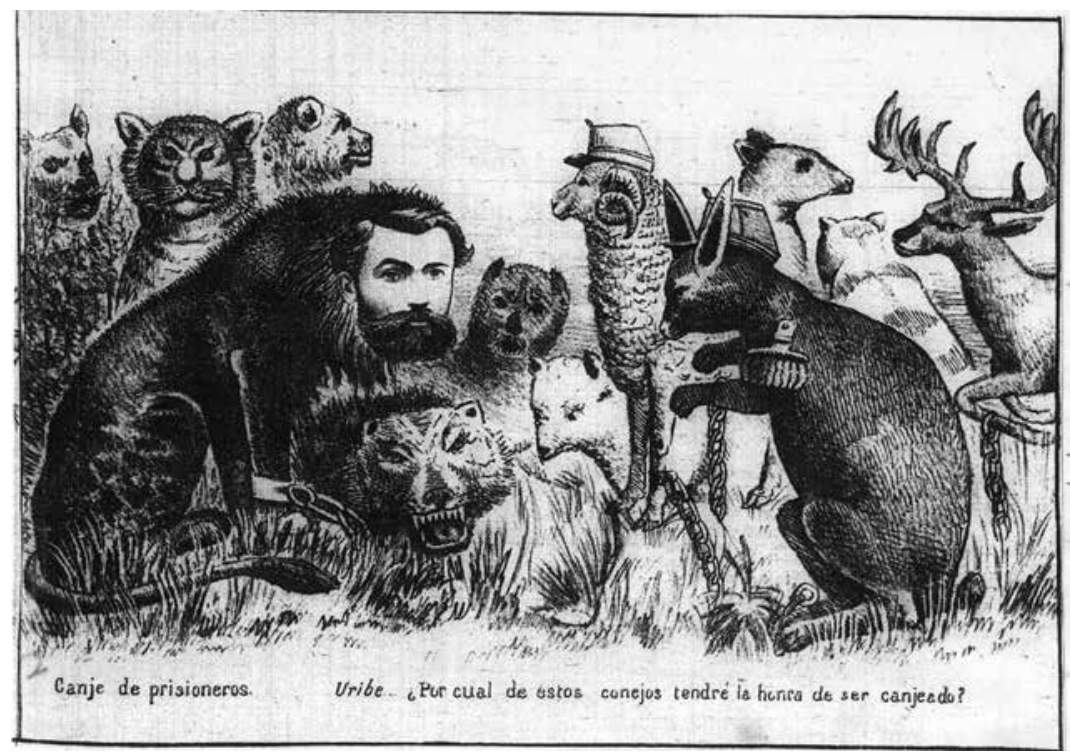

Figura 2. El Barbero (Santiago). Noviembre 15 de 1879. 


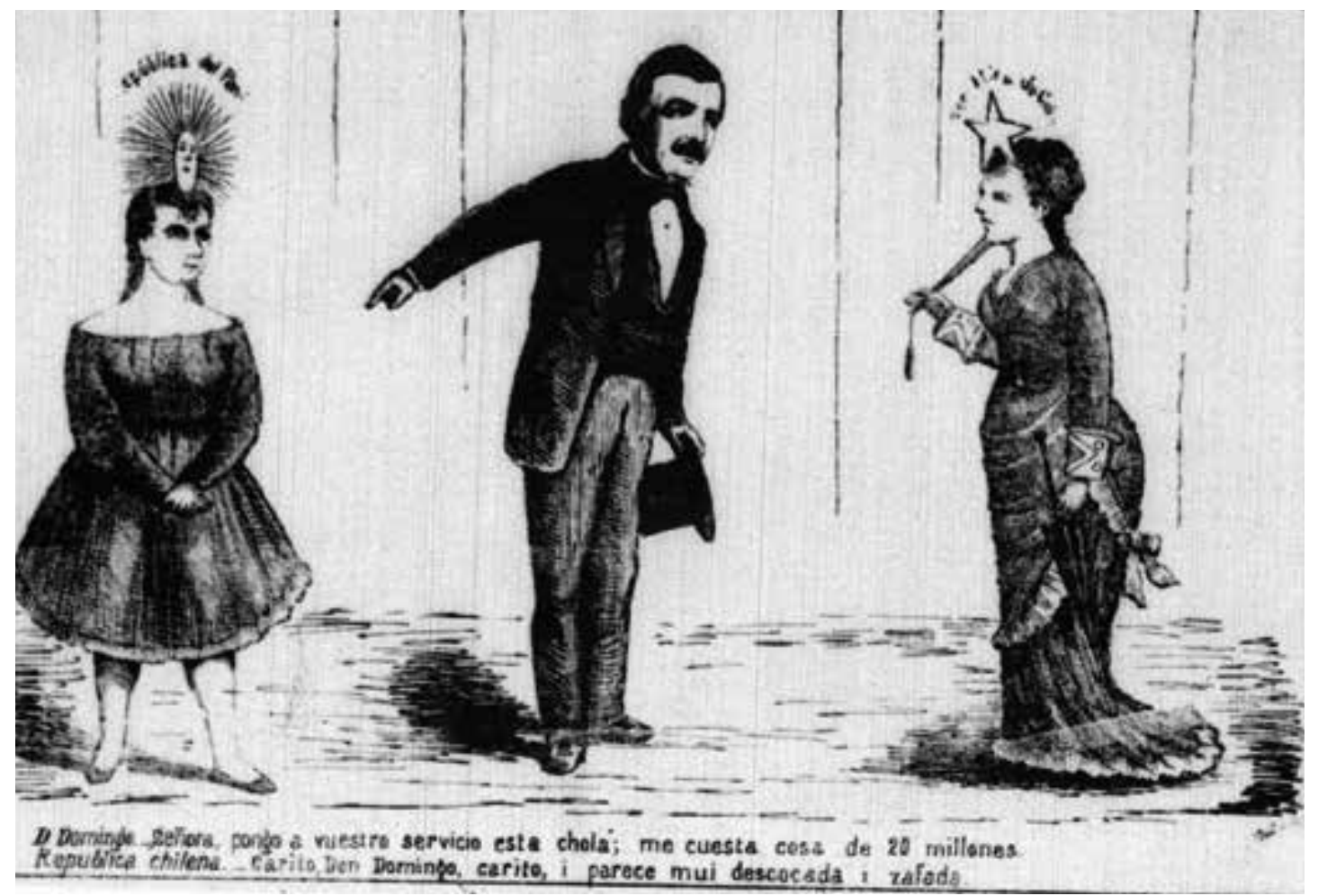

Figura 3. El Barbero (Santiago). Noviembre 29 de 1879.

palabras del artista. Por su parte, la de Chile es coronada por una estrella y ataviada con atuendos de dama de alcurnia, materializándose gráficamente la idea de superioridad de chilenos por sobre los peruanos (Figura 3).

Por su parte El Ferrocarrilito, primer periódico de caricaturas donde participó Juan Rafael Allende durante los años de la guerra, era un rotativo de batalla que se caracterizaba por un discurso visual y escrito particularmente ácido. El 9 de abril de 1880 en su portada publicó una ilustración donde el "General Pililo", representación del soldado chileno y símil del roto, se yergue orgulloso y triunfante ante Perú y Bolivia. La caricatura, publicada en pleno desarrollo de la Campaña de Tacna y Arica, muestra al chileno vestido de poncho, portando en sus manos un rifle y un cuchillo corvo mientras se ríe sardónicamente de sus enemigos. El Perú convertido una serpiente, perdió su cola donde se lee "Tarapacá", en alusión a la región conquistada por Chile en la primera fase terrestre de la guerra (noviembre de 1879). Por su parte, Bolivia aparece como un indígena inválido y esquelético en actitud de pedir clemencia (Figura 4).

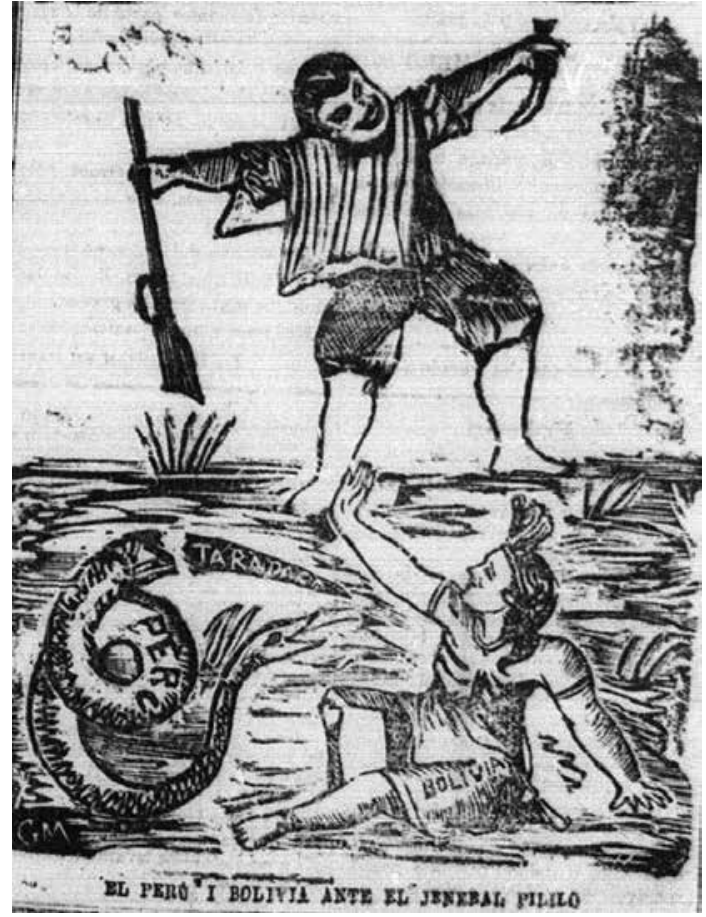

Figura 4. El Ferrocarrilito (Santiago). Abril 9 de 1880. 
En efecto, el verso que acompaña la imagen, firmado con el seudónimo de "Redactor n ${ }^{\circ} 10$ ", describe el diálogo de las tres Repúblicas. Bolivia dice:

"Noble Perú! Aliado mío,

Presta socorro a tu hermana!

Nada puedo hacer... mis hijos

Me tienen pobre y postrada...

En guerras civiles siempre,

Siempre en duelos y matanzas,

Mi erario han empobrecido

Y me han dejado sin blanca".

A renglón seguido el Perú le contestó:

"Yo no puedo darte ayuda

Porque también desmembrada

Me encuentro sin una libra...

Y... la caridad por casa...

La cola me cortó Chile,

Que es lo que más me hace falta,

Y se llevó, con mi cola.

Mis no muy repletas arcas.

Para de apuros salir

Sacar pienso a usted, hermana,

Una lonja que de mis pérdidas

En esta guerra resarga".

Por su parte Chile, el "General Pililo", al observar la escena les espetó:

"Ja! ja! ja! Qué divertido!

Van a pelear las aliadas!..."

Ante ello Perú y Bolivia imprecan:

“¡Socorro! ¡Misericordia!”

$\mathrm{Al}$ respecto Chile retrucó:

"No perdono las infamias

De naciones corrompidas,

En el vicio encenagadas,

Ociosas y bochincheras,

Viles, tramposas e ingratas!' (El Ferrocarrilito 1880)

A casi un mes de finalizada la campaña de Tacna y Arica (marzo-junio de 1880), marcada por la apropiación por parte de los chilenos de la provincia de Moquegua y más importante aún, el fin de la cooperación efectiva de peruanos y bolivianos tras el revés que sufrieron en el Campo de Alianza (26 de mayo), El Ferrocarrilito dio a la luz una caricatura del 7 de julio de 1880 , donde satirizó con los futuros defensores de Lima. El grabado muestra a uno de los soldados de Nicolás de Piérola, encargados de la defensa de la "Ciudad de los Reyes", como un personaje desgarbado, de baja estatura, de rasgos simiescos y de aspecto timorato (Figura 5).

El verso que acompaña la imagen dice, sardónicamente, que:

"Lima, la ciudad del sol,

Que hundirse hasta el tope piensa,

Ha confinado su defensa

A este hijo de español

Como él con sus seis millones

De valerosos soldados, Muy fuertes, pero gastados,

De... de puro maricones" (El Ferrocarril 1880).

A comienzos de 1881 apareció en Santiago el El Corvo, cuyo título aludía al yatagán utilizado por los soldados chilenos en campaña. Publicó una caricatura para burlarse del defenestrado gobernante boliviano Hilarión Daza, y por extensión a sus

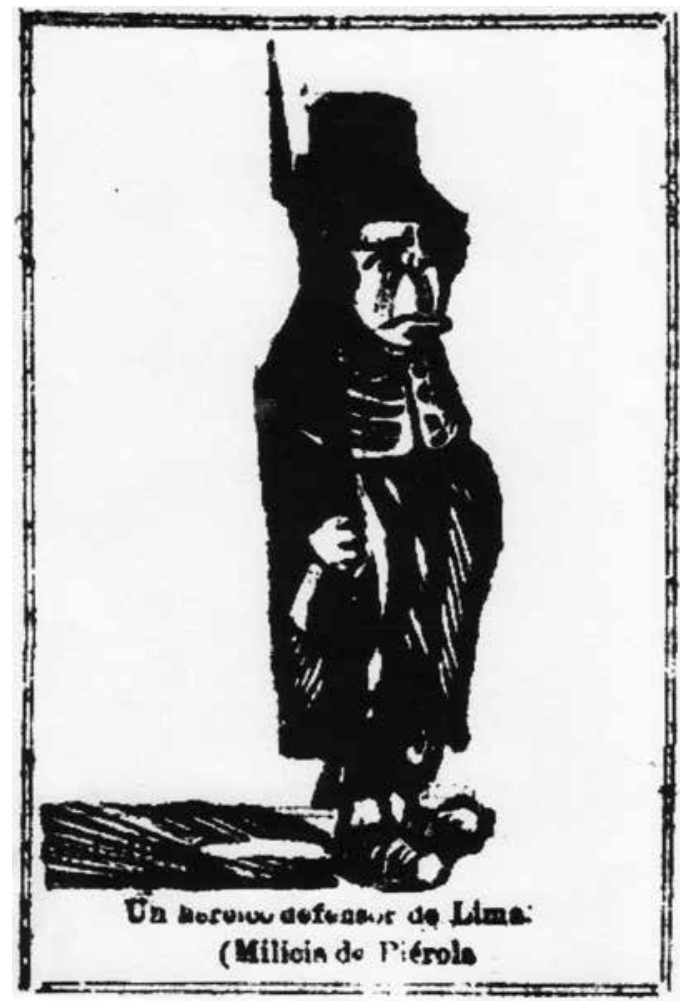

Figura 5. El Ferrocarrilito (Santiago). Julio 7 de 1880. 
compatriotas. En ella aparece un soldado chileno que encuentra en Arica una bota maloliente, la que según reza la leyenda del dibujo perteneció a Daza. Ante tan desagradable hallazgo, el infante tapándose su nariz, dice, se fortifica. Este grabado fue incluido en la edición del 26 de febrero de 1881, a más de un mes de las victorias chilenas en San Juan, Chorrillos y Miraflores, consideradas en ese momento como las que habían de terminar con la guerra. (Figura 6).

Por su parte, El Padre Cobos fue el más destacado periódico satírico chileno del último cuarto del siglo XIX. Se inspiró en la afilada pluma de Juan Rafael Allende y en las ilustraciones de Luis Fernando Rojas y Benito Basterrica. La gran variedad de temas de contingencia desmenuzados en sus páginas, a veces con decidida malquerencia y vehemencia, le hizo ganarse tanto adherentes fanáticos como detractores acérrimos. Se abanderizó con la causa chilena en la guerra, así como con la separación del Estado y la Iglesia, la ampliación de los derechos políticos de los ciudadanos, entre otras materias. Su primera época se publicó en Santiago en 1875 y la segunda en 1877. En estas líneas se hace alusión a los grabados publicados en su tercera y cuarta época, que vieron la luz entre $1881-1883$ y $1883-1885$. En todas sus caricaturas aparecían dos personajes: "El Padre Cobos", personificación del diario, y su fiel asistente "El Negro", que podían participar de la acción cómica o bien eran observadores de ella.

El 14 de noviembre de 1882 El Padre Cobos publicó un grabado donde se muestra cómo la República de Chile, de pie sobre el pabellón peruano, portando bizarramente una corona de laureles y sosteniendo su bandera, mira con desdén a su símil del Perú, la que se encuentra de rodillas con ademán de ruego. Tras ellas se observan los trofeos obtenidos por Chile desde 1879 a la fecha (el Perú, Bolivia, armas, municiones y varios emblemas militares) además de un grupo de personas que acongojadas y pobremente vestidas observan la humillación de su patria. El padre Cobos mira la escena sobre otro montón de blasones y artefactos de guerra, mientras el Negro cuchichea al oído de la república de Chile. Según reza el verso que acompaña esta caricatura, Perú le suplica a Chile brinde su protección y ayuda para aliviar los males que la aquejan, pues ninguno de sus gobernantes ha podido dar solución a ellos. Así, el grabado alude a que el gobierno de ocupación chileno ha sido el mejor de su historia (Figura 7):

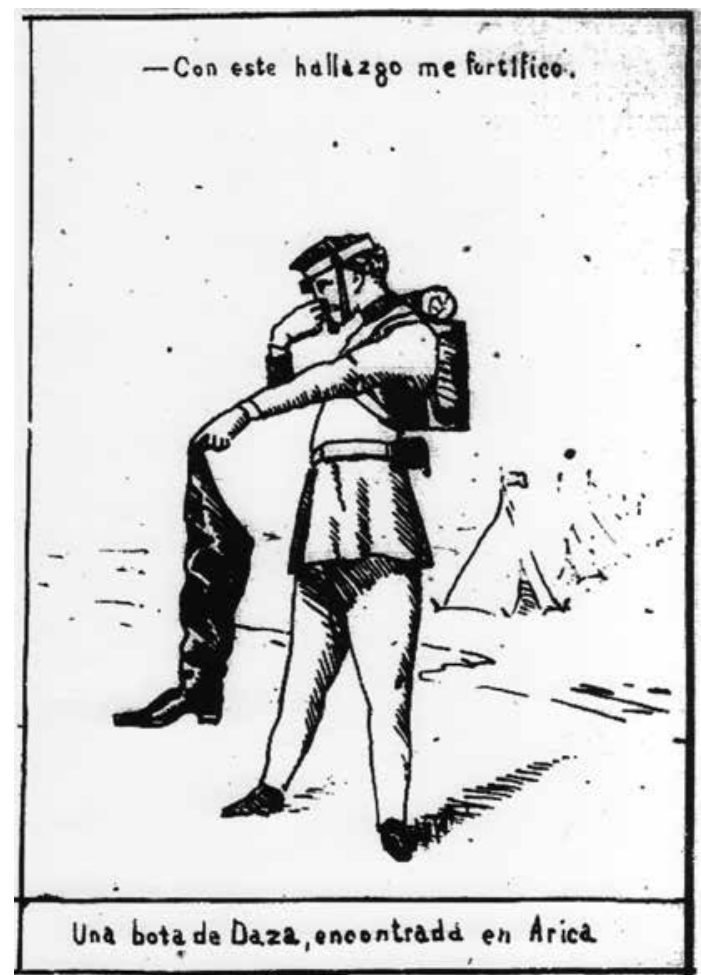

Figura 6. El Corvo (Santiago). Febrero 26 de 1881.

"Bajo tu suave gobierno,

Que es de justicia y de paz,

Nos libramos del infierno

De tanto cholo rapaz

Que, una vez en el poder,

A dos manos han robado

Mis arcas y me han dejado

Sin un hueso que roer" (el padre Cobos 1882).

Concordante con la imagen anterior se encuentra la caricatura titulada "Una tierna despedida" publicada en el día 5 de abril de 1884 , cuando en la práctica la guerra había finalizado. El dibujo muestra cómo el general peruano Miguel Iglesias, "Presidente regenerador del Perú", que pactó con los chilenos la paz a costa de ceder la rica provincia salitrera de Tarapacá, además de someter a un arreglo posterior la posesión de Arica y Tacna, y Jovino Novoa ministro de Chile en Lima y negociador de los acuerdos de paz, se abrazan mientras las tropas de chilenas, incluyendo al padre Cobos y al "negro" se retiran de la Ciudad de los Reyes. Iglesias porta un sable, símbolo de poder militar, y Novoa tiene en su bolsillo tan solo un rollo 


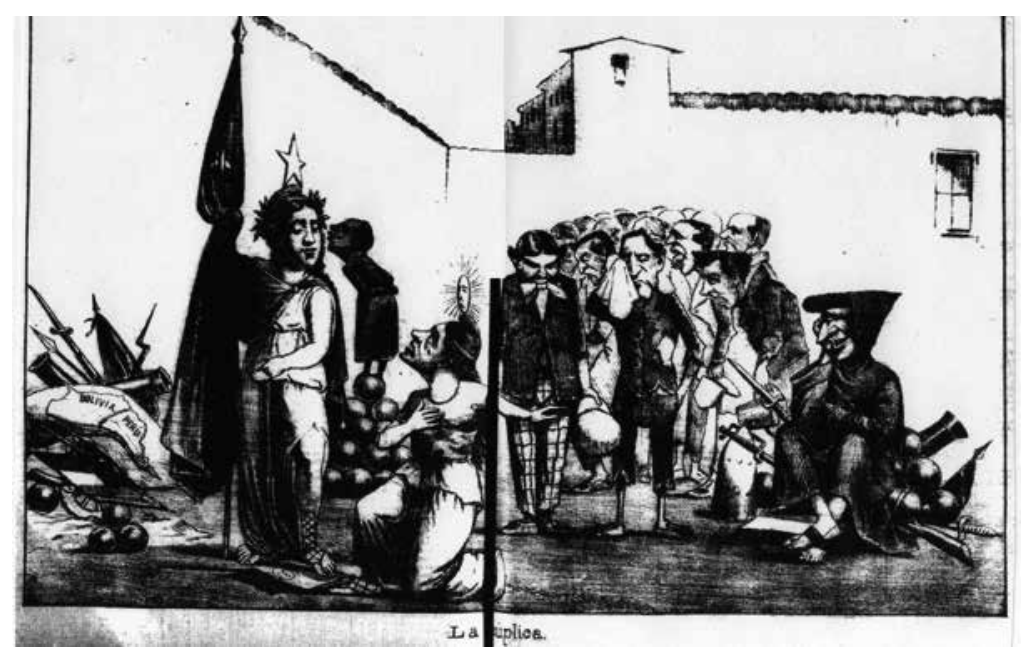

Figura 7. El Padre Cobos (Santiago). Noviembre 14 de 1882.

de papeles, probablemente en alusión al Tratado de Ancón firmado el 20 de octubre de 1883. La escena es observada por la República del Perú, representada por una mujer desconsolada sobre la que pende la espada de Damocles, pues a la salida de los chilenos el país queda abandonado a su suerte ante chinos, negros y mestizos de los cuales algunos portan cuchillos (Figura 8).

En un fragmento del verso que acompaña la caricatura, el general Iglesias le dice a Novoa:
“-Si supiera cuanto siento

Que su ejército se vaya!...

¿Quién pondrá después a raya

A ese populacho hambriento?" (el padre Cobos 1884).

Así, en la interpretación de la caricatura, pese a la derrota, Perú se vio beneficiado con la presencia de los chilenos en su capital y su salida implicaba un serio perjuicio y el riesgo cierto de la anarquía a manos del populacho hambriento.

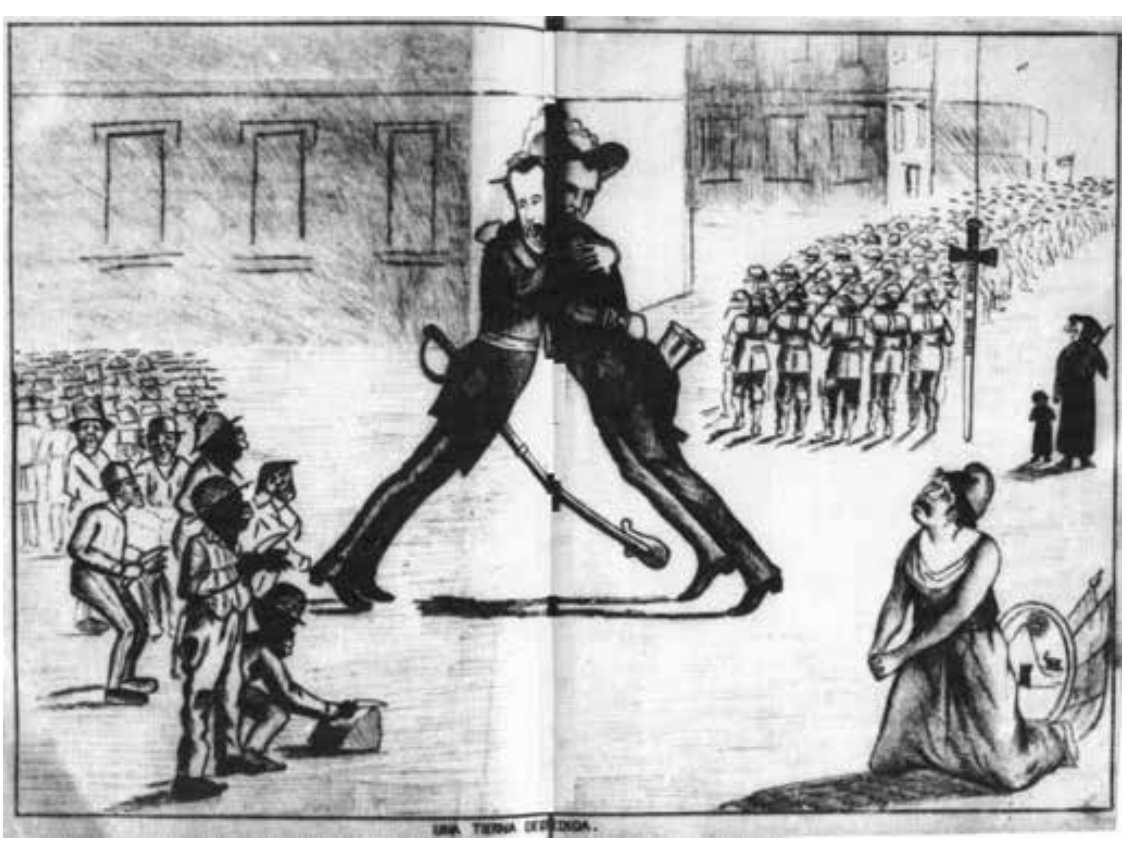

Figura 8. El Padre Cobos (Santiago). Abril 5 de 1884. 


\section{Reflexiones finales}

La guerra del Pacífico motivó la movilización a gran escala de un gran número de chilenos. Una parte vistió de uniforme y acudió al frente de batalla para matando y muriendo en tierra extraña vencer a sus adversarios, mientras tanto que en las redacciones de los periódicos de sátira, escritores, poetas y dibujantes blandieron sus afilados lápices y pinceles para desde su trinchera combatir a los adversarios de Chile. En su caso, los equipos editoriales lo hicieron ridiculizándolos.

Concordante con la línea editorial de la prensa chilena de noticias, que vilipendió sin tapujos a peruanos y bolivianos durante los años del conflicto, la de humor escrito y gráfico también colaboró con el descrédito de los enemigos de Chile presentándolos siempre en un plano de diferenciación respecto de los chilenos. Construyeron un "otro" a partir de su difamación, anclándose en el rescate y construcción simbólica del adversario a derrotar.

Peruanos y bolivianos, sin distinción de clase o sexo, fueron presentados como cobardes, desvencijados, malos combatientes, indigentes, entre otras apreciaciones negativas. Afirmaciones que no necesariamente se ajustaban a la realidad de los hechos, pero que recogieron parte de lo que se decía en el momento y colaboró para la creación y consolidación de un estereotipo que se repitió y persistió en el tiempo, fundamentado en las sucesivas victorias de las tropas chilenas y luego con el triunfo final de Chile sobre Perú y Bolivia. Así, el triunfo militar dio paso a la imposición de un canon de apreciación de sus enemigos del norte. Esa fue la idea fuerza desplegada en escritos y caricaturas.

Fueron caricaturas ofensivas apoyadas en prejuicios existentes, que facilitaron la creación de nuevos prejuicios, donde se combinó el nacionalismo bélico con la burla, provocación, la insolencia e incorrección política, propios del lenguaje de la sátira visual y escrita.

Aquel discurso y retórica escrita y visual apeló a diversas formas para representar las ideas a materializar en un dibujo satírico. Aves de poco valor, conejos, cabras, sirvientas, serpientes, humanos de rasgos simiescos, esclavos, aristócratas empobrecidos, chinos y negros. Incluso se utilizó la figura de la "Marianne" de la Revolución Francesa, aunque desvencijada, para personificar a la República del Perú.

Así, para los caricaturistas de los periódicos de sátira chilenos, el general Pililo se impuso ante sus enemigos en los combates de la pluma y la tinta, al igual que lo hizo en los campos de batalla.

\section{Referencias Citadas}

Arellano, J.C.

2012 Discursos racistas en Chile y Perú durante la Guerra del Pacífico. Estudos Ibero-Americanos 38, 2: 239-264.

Arellano, J.C.

2014 La Guerra del Pacífico y el americanismo republicano en el discurso bélico peruano. História Unisinos 18, 2: 392-402.

Burke, P.

2001 Visto y no visto. El uso de la imagen como documento histórico. Barcelona, Crítica.

Cid, G.

2009 Un icono funcional: la invención del roto como símbolo nacional. 1870-1888. En Nación y nacionalismo en Chile. S. $X I X$, Vol. 1, editado por Gabriel Cid y Alejandro San Francisco, pp. 221-254, Centro de Estudios Bicentenario, Santiago.

Cid, G.-Vergara, J.

2011 Representando a la "Copia Feliz del Edén”. Rugendas: Paisaje e identidad nacional en Chile, siglo XIX. Revista de Historia Social y de las mentalidades 15, 2: 109-135.

Collier, S.

2005 Chile. La construcción de una república. 1830-1865. Política e ideas. Ediciones Universidad Católica de Chile, Santiago.

Cornejo, J.

2006 La República como mujer en los periódicos de Juan Rafael Allende: un discurso político en caricaturas. Mapocho 59: 11-46.
Crespi, I.

1997 El proceso de opinión pública. Cómo habla la gente, Ariel, Barcelona.

Cruz de Amenabar, I. y Zaldívar, T.

1996 El trazado fronterizo de la caricatura. Confrontación y cohesión en el proceso limítrofe chileno. 1879-1902. Boletín de la Academia Chilena de la Historia 106: 105-158.

Cruz de Amenazar, Isabel.

1997 Diosas atribuladas: alegorías cívicas, caricatura y política en Chile durante el siglo XIX. Historia 30: 127-171.

Guerrero Y., C.

1996 Los capitanes de la industria a través de las caricaturas contemporáneas, 1870-1920. Cuadernos de Historia 16: 133-171.

González Bernaldo de Quirós, P.

1999 Literatura injuriosa y opinión pública en Santiago de Chile durante la primera mitad del siglo XIX. Estudios Públicos 76. Centro de Estudios Públicos, Chile: 233-262. Fermandois, J.

2005 Mundo y fin de mundo. Chile en la política mundial, 1900-2004. Ediciones Pontificia Universidad Católica de Chile, Santiago, 2005.

Ibarra, P.

2014 Liberalismo y prensa: Leyes de imprenta en el Chile decimonónico (1812-1872). Revista de Estudios Histórico Jurídicos, 36: 293-313. 
Ibarra, $\mathrm{P}$

2013 Veteranos y prensa satírica: desmovilizados e inválidos en los periódicos chilenos de caricaturas durante la Guerra del Pacífico (1879-1884). Universum, 28, 2: 59-81.

LeShan, L.

1992 La psicología de la guerra. Un estudio de mística y su locura. Editorial Andrés Bello, Santiago.

Mc Evoy, C.

2012 Civilización, masculinidad y superioridad racial: una aproximación al discurso republicano chileno durante la Guerra del Pacífico (1879-1884). Revista de sociología e política, 20, 42: 73-92.

Mc Evoy, C.

2011 Guerreros civilizadores. Política, sociedad y cultura en Chile durante la Guerra del Pacífico, Ediciones Universidad Diego Portales, Santiago.

Ossandón, C.

1998 El crepúsculo de los sabios y la irrupción de los publicistas, LOM, Santiago.

Pardos-Prado, $\mathrm{S}$.

2006 ¿Qué es y cómo se crea la opinión pública? En Anduiza, E. Opinión pública y medioambiente. Monografías de educación ambiental, SBEA, SCEA, Barcelona.

Rubilar, M.,

2010 "Escritos por chilenos, para los chilenos y contra los peruanos": la prensa y el periodismo durante la Guerra del
Pacífico (1879-1883), en Chile y la Guerra del Pacífico, editado por Carlos Donoso y Gonzalo Serrano, Centro de Estudios Bicentenario, Santiago.

Salinas, M. et al.

2011 El que ríe último... caricaturas y poesías en la prensa humorística chilena del siglo XIX. Centro de Investigaciones Diego Barros Arana, Santiago.

Salinas, M.

2005 Erotismo, humor y trasgresión en la obra satírica de Juan Rafael Allende. Mapocho 57: 199-248.

Salinas, M.

2006 Y no se ríen de este leso porque es dueño de millones!: El asedio cómico y popular de Juan Rafael Allende a la burguesía chilena del siglo XIX, Historia 39: 231-262.

Sater, W.

1986 Chile and the War of the Pacific, University of Nebraska, Lincoln.

Zaldívar, T.

2004 "El papel de los monos". Breve crónica de un tercio de siglo de prensa de caricatura 1858-1891, En Entre tintas y plumas. Historias de la prensa chilena del Siglo XIX, editado por Ángel Soto, pp. 139-178. CIMA, Universidad de los Andes, Santiago.

\section{Notas}

1 Durante la guerra, la prensa de noticias y la satírica ensalzó la actuación del roto, representante del bajo pueblo, en los campos de batalla transformándolo en un ícono nacional y referente obligado cuando se trataba de exaltar las virtudes patrióticas y guerreras del chileno en campaña (Cid 2009).

2 Pese a tratarse de un concepto de difícil definición, la opinión pública podría entenderse como el fenómeno social, donde por los medios de comunicación se construye un espacio público de intercambio y discusión de ideas, practicándose una crítica constante a las fuerzas políticas en pugna, las instituciones de la Sociedad Civil, los organismos de gobierno y el poder del Estado. Según Irving Crespi, la conformación de la opinión pública se trata de un proceso interactivo y multidimensional, donde las posturas de los individuos se forman y cambian, en que las apreciaciones de las personas se transforman en una fuerza colectiva que se pronuncia en términos comunes, la que es integrada en la conducción de los asuntos del Estado. Así, individuo y grupo actúan en conjunto en "un flujo interminable que va continuamente de las posturas individuales a las coaliciones de opiniones y viceversa" (Crespi 1997). De ese modo, expresiones tales como "la opinión pública ha hablado", o el "juicio del tribunal de la opinión" no son otra cosa que metáforas periodísticas íntimamente ligadas al ideal liberal que supone la existencia de un debate informado y racional, pues no se trata que el cuerpo social haya alcanzado un acuerdo en los temas en debate, sino que se ha producido un nuevo equilibrio de poder político al respecto (Pardos-Prado 2006 y González 1999). Carmen McEvoy sostiene que durante los años de la guerra los editores de los periódicos "definieron lo público como instancia de socialización y mediación de lo individual y al mismo tiempo confeccionaron un mapa cognitivo de la guerra que Chile enfrentaba con sus vecinos". Asimismo, la prensa actuó como "centro de noticias, organizadora de múltiples rituales patrióticos, integradora de valores divergentes, tribuna del pueblo, una veces consejera y otra crítica del gobierno, además de núcleo de una retórica republicano-nacionalista" (McEvoy 2011). Todo aquello en el contexto de tolerancia temática y de contenidos otorgado por la libertad de prensa consagrada en la ley de 1872 (Ibarra 2014).

3 No cabe pronunciarse aquí respecto de la discusión teórica a propósito de las implicancias, contenidos e interpretaciones aparejadas al concepto "representación", pues la extensión y propósito de este escrito lo impiden. Con todo, para el caso concreto de su utilización en la caricatura contemporánea a la Guerra del Pacífico, se entenderá como tal, parafraseando a Gabriel Cid y Jacinta Vergara en su escrito a propósito de la representación del paisaje e identidad nacional en la obra de Rugendas durante el siglo XIX, a la reelaboración personal y colectiva de estereotipos nacionales específicos en que se plasman bagajes culturales, lecturas, técnicas, apreciaciones simplificadas, prejuicios, memorias históricas y juicios de valor, que confluyen en una determinada percepción de los enemigos del país, situándolo desde esta perspectiva en el marco de un enfrentamiento bélico (Cid y Vergara 2011).

4 El método utilizado para analizar las caricaturas presentadas en este escrito está basado en los planteamientos de los miembros de la Escuela de Warburg durante la primera mitad del siglo XX, además de algunas de las propuestas del historiador británico Peter Burke expresadas en su libro Visto y no visto. El uso de la 
imagen como documento histórico. En síntesis, se trata de la descripción de las imágenes (iconografía), como lo sugirió Edwin Panofsky en 1939, distinguiendo tres niveles de significado en cada obra. El primero de ellos está relacionado con la denominada "descripción preiconográfica", referida al "significado natural" de los elementos incluidos en una caricatura, es decir, identificar los objetos (personas, armas, emblemas, etc.) y situaciones (batallas, reuniones, conversaciones, etc.). El nivel siguiente trata del estudio iconográfico en sentido estricto, entregando el "significado convencional" de las imágenes donde se identifica y define el acontecimiento al que se refiere el dibujo para no confundirlo con otro. Finalmente se procede a la interpretación iconológica, donde cada grabado fue colocado en su contexto histórico y material, en búsqueda de su significado y de la orientación intrínseca del testimonio visual referida al fenómeno estudiado (Burke 2001).

5 La obra de Carmen McEvoy, Guerreros civilizadores, ya citada, permite conocer el impacto y trascendencia del conflicto en la Sociedad Civil en el plano emocional, discursivo, simbólico y cultural, a partir de la retórica y discurso nacionalista desplegado por las autoridades, instituciones y prensa contemporáneas, que ha dejado una huella indeleble en la memoria histórica de los chilenos, más allá de si efectivamente Chile llevó adelante una "cruzada civilizadora" que legitimó el uso de la fuerza, como lo propone la historiadora peruana en su obra (Mc Evoy 2011). En ese mismo sentido, debe tenerse en cuenta lo afirmado por William Sater en Chile and the War of the Pacific quien, al analizar la vida cotidiana del "frente interno" durante el conflicto a partir del análisis de un gran volumen de periódicos y documentación de archivo, afirma que la guerra del Pacífico no cambió dramáticamente la sociedad chilena a nivel político, pues no se involucró en una "guerra total"; en tanto no se modificó el sistema económico, los aliados nunca amagaron su territorio, no hubo carestía de alimentos y, sobre todo, la estructura social no se modificó sustancialmente (Sater 1986).

6 Isabel Cruz de Amenabar y Trinidad Zaldívar en su artículo "El trazado fronterizo de la caricatura. Confrontación y cohesión en el proceso limítrofe chileno. 1879-1902", estudian algunas caricaturas publicadas durante el periodo de la guerra desde la perspectiva de la presentación lúdica de los hechos, recurriendo a la ironía y la parodia transformado el conflicto en "juego de niños" por parte de editores de periódicos y dibujantes haciendo la información asequible a la "mayoría del país" (Cruz de Amenábar y Zaldívar 1996). Por su parte, quien escribe estas líneas presenta la visión de la prensa de caricaturas respecto de la problemática de los veteranos y mutilados de la guerra en "Veteranos y prensa satírica: desmovilizados e inválidos en los periódicos chilenos de caricaturas durante la Guerra del Pacífico (1879-1884)" (Ibarra 2013).

7 La mujer era la materialización de la República, en alusión a Marianne que representó a la República Francesa, legado directo de la Revolución de 1789 aunque sus orígenes se remontan a la Antigüedad clásica. La imagen fue utilizada profusamente en la iconografía de los rotativos de humor político gráfico durante el siglo XIX e inicios del XX. En Chile, esta alegoría republicana tomó el cuerpo de una joven de cabello oscuro, rizado y suelto sobre sus hombros, vistiendo una túnica que caía en pliegues por su cuerpo esbelto. Su cabeza estaba coronada por una estrella solitaria, la misma de la enseña tricolor chilena. Así, la personificación femenina de la república no fue otra cosa que una alegoría visual de una idea política determinada, fundamental para el desarrollo y propagación del ideario liberal del último cuarto del siglo XIX, como lo es la defensa de la República y la institucionalidad asociada a ella, para asegurar el progreso del país y, teóricamente, inclusivo de todos los ciudadanos (Cruz 1997). 
